\title{
An efficient cyclocondensation reactions, antimicrobial activity and molecular orbital calculations of $\alpha$-benzopyrone derivatives
}

\author{
Hafez Mohamed El-Shaaer*, Salah Sayed Ibrahim, \\ Wafaa Ramzy Abd-Elmonem and Christine Gamal Ibrahim \\ Department of Chemistry, Faculty of Education, Ain Shams University, Roxy, 11711, Cairo, Egypt \\ *Corresponding author at: Department of Chemistry, Faculty of Education, Ain Shams University, Roxy, 11711, Cairo, Egypt. \\ Tel.: +2.02.0112627069; fax: +2.02.2581243. E-mail address: elshaaer@hotmail.com (H.M. El-Shaaer).
}

\section{ARTICLE INFORMATION}

Received: 15 October 2011

Received in revised form: 11 December 2011

Accepted: 26 December 2011

Online: 30 June 2012

\section{KEYWORDS}

\section{Synthesis}

$\alpha$-Benzopyrone

Cyclocondensation

Antimicrobial Activity

Chromeno[3,4-c]pyridinones

Molecular orbital calculations

\begin{abstract}
An efficient synthesis of 4,6,8-trimethyl-2-oxo- $2 \mathrm{H}$-chromene-3-carbonitrile (2) via Claisen condensation of 3,5-dimethyl-2-hydroxyacetophenone with ethyl cyanoacetate in the presence of sodium metal is reported. Cyclocondensation reactions of compound (2) with ethyl acetate or with ethyl cyanoacetate in the presence of ethoxide gave sodium salt of 7-amino-9-hydroxy-2,4-dimethyl-6H-benzo[c]chromen-6-one derivatives (3) and (4) respectively, which upon neutralization with $10 \%$ hydrochloric acid gave 7-amino-9hydroxy-2,4-dimethyl-6H-benzo[c]chromen-6-one (5). Hydrolysis of compound (2) with ethanolic sodium hydroxide solution gave 4,6,8-trimethyl-2-oxo-2 $\mathrm{H}$-chromene-3-carboxylic acid (6). Treatment of compound (2) with Vilsmier reagent using excess $\mathrm{POCl}_{3}$ gave 4-(chloro(formyl)methyl-6,8-dimethyl-2-oxo-2 $\mathrm{H}$-chromene-3-carbonitrile (7). Also, condensation of compound (2) with DMF-DMA in xylene or with $\mathrm{POCl}_{3} / \mathrm{DMF}$ in pyridine gave the same product 4-((E)-2-(dimethylamino)vinyl)-6,8-dimethyl-2-oxo-2H-chromene-3-carbonitrile (8). The cyclocondensation reactions of compound (8) with hydroxylamine hydrochloride, urea, and with hydrazinecarbodithioic acid gave 3,4-dihydro-3-hydroxy-4imino-7,9-dimethylchromeno[3,4-c]pyridin-5-one (9), 4-imino-7,9-dimethyl-5-oxo-4H-chromeno[3,4-c]pyridine-3(5H)-carboxamide (10) and 3-amino-3,4-dihydro-4-imino-7,9-dimethyl chromeno[3,4-c]pyridin-5-one (11), respectively. Also, acid hydrolysis of compound (8) gave 7,9-dimethyl-3H-chromeno[3,4-c]pyridine-4,5-dione (12). Structures of the products were established on the basis of elemental analysis, IR, ${ }^{1} \mathrm{H}$ and ${ }^{13} \mathrm{C}$ NMR, mass spectra and semiempirical AM1-M0 calculations. The antimicrobial activities of the synthesized products were also studied.
\end{abstract}

\section{Introduction}

$\alpha$-Benzopyrone derivatives constitute an important class of oxygenated heterocycles [1]. Many compounds containing the benzopyrone nucleus, both naturally occurring and synthetic, are known to exhibit pharmacological activity such as antifungal [2-4], antibacterial [5], anti-mycobacterial [6,7], anticoagulants $[8,9]$, inhibitors of some enzymes $[10,11]$, and antitumor [12-14]. With the expectations to find biological activity, we decided to investigate the synthesis of some novel systems of $\alpha$-benzopyrone derivatives bearing fused and isolated moiety. Recently, the synthesis [15], photochemical [16] and theoretical $[1,2,17]$ properties of $\alpha$-benzopyrone derivatives were investigated.

The aim of the present paper is to investigate an efficient synthesis of coumarin derivatives containing active methyl and cyano groups and study their cyclocondensation reactions with ethyl acetate, ethyl cyanoacetate, hydroxylamine hydrochloride, urea, and with hydrazine carbodithioic acid. The condensations of 4-methyl group of coumarin derivatives with Vilsmier reagents at different conditions and with DMF-DMA were also studied.

The antimicrobial activities for the prepared compounds were investigated. Also, semi-empirical AM1 and $A b$ Initio (STO-3G) molecular orbital calculations for the new

\section{European Journal of Chemistry}

compounds were performed and compared with their experimental data.

\section{Experimental}

\subsection{Instrumentation}

The uncorrected melting point was determined in an open

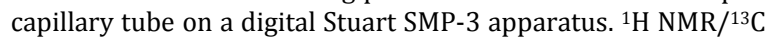
NMR spectra were obtained on a $300 \mathrm{MHz} / 75.46 \mathrm{MHz}$ Varian Mercury VX-300 NMR spectrometer in DMSO- $d_{6}$ with tetramethylsilane as an internal standard. Elemental analyses were performed on Vario El Elementar apparatus. IR spectra were recorded on FTIR Nicolet IS10 spectrophotometer $\left(\mathrm{cm}^{-1}\right)$, using $\mathrm{KBr}$ disks. Mass spectra recorded on a Gas Chromatographic GCMSqp 1000 ex Shimadzu instrument at 70 $\mathrm{eV}$.

The chemicals were purchased from the suppliers as the highest purity grade. The theoretical data which were obtained from molecular mechanical calculations on the basis of the semi-empirical AM1 and Ab Initio (STO-3G) methods of HyperChem 8.03 computer program. 


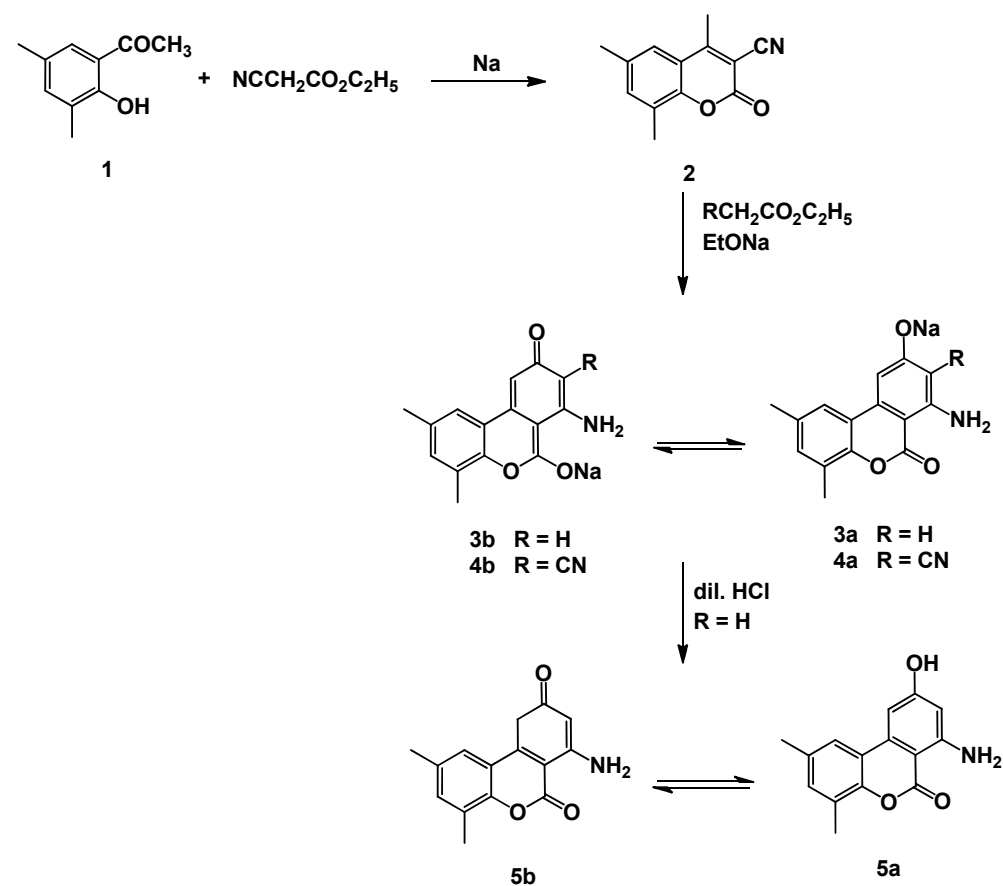

Scheme 1

\subsection{Synthesis}

\subsubsection{4,6,8-Trimethyl-2-oxo-2H-chromene-3-carbonitrile (2)}

Sodium metal ( $2 \mathrm{~g}, 8.6 \mathrm{mmol})$ was added in small portion to a solution of 3,5-dimethyl-2-hydroxyacetophenone (1) (4 g, 2.4 mmol) in ethyl cyanoacetate $\left(30 \mathrm{~cm}^{3}\right)$. The reaction mixture was heated on water-bath for $3 \mathrm{~h}$, and then cooled to room temperature, treated with ethanol $\left(10 \mathrm{~cm}^{3}\right)$ and refluxed for 1 $\mathrm{h}$. The solid obtained was filtered, and crystallized from ethanol to give (2) as pale green crystals (Scheme 1). Yield: 62\%. M.p.: 200-202 ${ }^{\circ} \mathrm{C}$. FT-IR (KBr, cm $\left.{ }^{-1}\right): 3072$ (CHarom.), 2921, 2953 ( $\mathrm{CH}_{\text {aleph. }}$ ), 2230 (CN), 1721 (C=0), 1608 (C=C). ${ }^{1} \mathrm{H}$ NMR (300 MHz, DMSO- $\left.d_{6}, \delta, \mathrm{ppm}\right): 2.26\left(\mathrm{~s}, 3 \mathrm{H}, \mathrm{CH}_{3}\right), 2.31\left(\mathrm{~s}, 3 \mathrm{H}, \mathrm{CH}_{3}\right), 2.61$ (s, 3H, $\left.\mathrm{CH}_{3}\right), 7.42$ (s, $\left.1 \mathrm{H}, H-7\right), 7.49$ (s, $\left.1 \mathrm{H}, H-5\right) .{ }^{13} \mathrm{C}$ NMR $(75$ MHz, DMSO- $\left.d_{6}, \delta, \mathrm{ppm}\right): 24.2,27.7,29.6,109.9,123.5,126.7$, 133.6, 134.9, 143.6, 146.7, 158.3, 165.9, 172.9. MS (EI, $\mathrm{m} / \mathrm{z}$ (\%)): $212.4(\mathrm{M}-1,86.9), 212.8\left(\mathrm{M}^{+}, 100\right), 213.8(\mathrm{M}+1,14.5)$. Anal. calcd. for $\mathrm{C}_{13} \mathrm{H}_{11} \mathrm{NO}_{2}$ : C, 73.23; $\mathrm{H}, 5.20 ; \mathrm{N}, 6.57$. Found: C, 73.10; H, 5.00; N, 6.60\%.

\subsubsection{Sodium salt of 7-amino-9-hydroxy-2,4-dimethyl-6H- benzo[c]chromen-6-one derivatives (3) and 7-amino-9- hydroxy-2,4-dimethyl-6H-benzo[c]chromen-6-one (5)}

A solution of compound (2) $(2.0 \mathrm{~g}, 0.93 \mathrm{mmol})$ in ethoxide ( $1.0 \mathrm{~g}$ sodium, $40 \mathrm{~cm}^{3}$ absolute ethanol), and then ethyl acetate $\left(24 \mathrm{~cm}^{3}\right)$ was added and the mixture was refluxed on waterbath for $3 \mathrm{~h}$, cooled to room temperature, treated with diethyl ether $\left(40 \mathrm{~cm}^{3}\right)$. The solid obtained was filtered, and crystallized from diethyl ether to give (3) as pall-yellow crystals (Scheme 1 and 2). Yield: $89 \%$. M.p.: $168-170^{\circ} \mathrm{C}$. The compound (3) $(0.5 \mathrm{~g}$, $0.18 \mathrm{mmol}$ ) was acidified with $10 \% \mathrm{HCl}$ and the solid obtained was filtered, and crystallized from water to give (5) as pallyellow crystals (Scheme 1 and 2). Yield: 89\%. M.p.: 166-169 ${ }^{\circ} \mathrm{C}$.

7-Amino-9-hydroxy-2,4-dimethyl-6H-benzo[c]chromen-6-one derivatives (3): FT-IR $\left(\mathrm{KBr}, \mathrm{cm}^{-1}\right)$ : 3309, 3489 (br., $\mathrm{NH}_{2}$ ), 2921 ( $\left.\mathrm{CH}_{\text {aleph. }}\right), 1721$ (w, $\left.\mathrm{C}=\mathrm{O}_{\text {coumarin }}\right), 1655$ (s, $\mathrm{C}=\mathrm{O}_{\text {cyclic ketone }) .}{ }^{1 \mathrm{H}} \mathrm{NMR}$ (300 MHz, DMSO- $\left.d_{6}, \delta, \mathrm{ppm}\right): 1.63(\mathrm{~s}, 2 \mathrm{H}, \mathrm{NH}$, exchangeable with $\mathrm{D}_{2} \mathrm{O}$ ), 2.22 (s, 3H, $\left.\mathrm{CH}_{3}\right), 2.28\left(\mathrm{~s}, 3 \mathrm{H}, \mathrm{CH}_{3}\right), 6.23$ (s, $1 \mathrm{H}, H-8$ ), $7.09(\mathrm{~s}, 1 \mathrm{H}, H-3), 7.19(\mathrm{~s}, 1 \mathrm{H}, H-1), 7.31(\mathrm{~s}, 1 \mathrm{H}, H-10)$.

7-Amino-9-hydroxy-2,4-dimethyl-6H-benzo[c]chromen-6-one (5): FT-IR (KBr, cm$\left.{ }^{-1}\right): 2922,3455$ (br., $\left.\mathrm{OH}, \mathrm{NH}_{2}\right), 1725$ (m, $\left.\mathrm{C}=\mathrm{O}_{\text {coumarin }}\right), 1666$ (s, $\mathrm{C}=\mathrm{O}_{\text {cyclic ketone). }}{ }^{1} \mathrm{H}$ NMR (300 MHz, DMSO$\left.d_{6}, \delta, \mathrm{ppm}\right): 2.29\left(\mathrm{~s}, 3 \mathrm{H}, \mathrm{CH}_{3}\right), 2.33\left(\mathrm{~s}, 3 \mathrm{H}, \mathrm{CH}_{3}\right), 3.83\left(\mathrm{~s}, 2 \mathrm{H}, \mathrm{NH}_{2}\right.$, exchangeable with $\left.\mathrm{D}_{2} \mathrm{O}\right), 6.22(\mathrm{~s}, 1 \mathrm{H}, \mathrm{OH}$, exchangeable with $\left.\mathrm{D}_{2} \mathrm{O}\right), 7.21(\mathrm{~s}, 1 \mathrm{H}, H-8), 7.26(\mathrm{~s}, 1 \mathrm{H}, H-3), 7.28(\mathrm{~s}, 1 \mathrm{H}, H-1), 7.37$ (s, $1 \mathrm{H}, H-10)$. ${ }^{13} \mathrm{C}$ NMR (75 MHz, DMSO- $d_{6}, \delta, \mathrm{ppm}$ ): 24.5, 25.3, 27.7, 29.8, 52.5, 53.8, 123.4, 127.8, 132.1, 132.7, 134.3, 142.7, 143.3, 143.9, 157.9, 166.8, 175.5. MS (EI, $m / z$ (\%)): $255.7\left(\mathrm{M}^{+}\right.$, 6.5). Anal. calcd. for $\mathrm{C}_{15} \mathrm{H}_{13} \mathrm{NO}_{3}$ : $\mathrm{C}, 70.58 ; \mathrm{H}, 5.13 ; \mathrm{N}, 5.49$. Found: C, 70.30; H, 4.90; N, 5.40\%.

\subsubsection{Sodium salt of 7-amino-9-hydroxy-2,4-dimethyl-6-oxo-} 6H-benzo[c]chromene-8-carbonitrile (4)

A solution of compound (2) (2 g, $0.93 \mathrm{mmol})$ in ethoxide ( $0.8 \mathrm{~g}$ sodium, $40 \mathrm{~cm}^{3}$ absolute ethanol), and then ethyl cyanoacetate $\left(9 \mathrm{~cm}^{3}\right)$ was added and the mixture was refluxed on water-bath for $3 \mathrm{~h}$, cooled to room temperature. The solid obtained was filtered, and crystallized from ethanol to give (4) as white crystals (Scheme 1 and 2). Yield: 31\%. M.p.: 183-185 ${ }^{\circ} \mathrm{C}$. FT-IR (KBr, cm$\left.{ }^{-1}\right): 3397$ (br., $\left.\mathrm{NH}_{2}\right), 2976\left(\mathrm{CH}_{\text {aleph. }}\right), 2263$ (CN), 1623 (br., C=0). MS (EI, $m / z$ (\%)): 301.0 (M-1, 16.7). Anal. calcd. for $\mathrm{C}_{16} \mathrm{H}_{11} \mathrm{~N}_{2} \mathrm{NaO}_{3}$ : C, 63.58; $\mathrm{H}, 3.67 ; \mathrm{N}, 9.27$. Found: $\mathrm{C}$, 63.10; $\mathrm{H}, 3.20 ; \mathrm{N}, 9.10 \%$.

\subsubsection{4,6,8-Trimethyl-2-oxo-2H-chromene-3-carboxylic acid} (6)

A solution of compound (2) $(0.5 \mathrm{~g}, 0.23 \mathrm{mmol})$ in ethanol (2 $\left.\mathrm{cm}^{3}\right)$, sodium hydroxide solution $(0.09 \mathrm{~g}$ sodium hydroxide, 2 $\mathrm{cm}^{3}$ water) was added and the mixture was refluxed for $2 \mathrm{~h}$, cooled to room temperature. The solid obtained was filtered, and crystallized from ethanol to give (6) as dark brown crystals (Scheme 3). M.p.: 206-207 ${ }^{\circ} \mathrm{C}$. Yield: 87\%. FT-IR $\left(\mathrm{KBr}, \mathrm{cm}^{-1}\right)$ : 3081 (br., OH), 2920, 2959 ( $\mathrm{CH}_{\text {aleph.) }}, 1742$ (s, C=Oacid), 1660 (br., $\mathrm{C}=\mathrm{O}_{\text {coumarin }}$ ). 

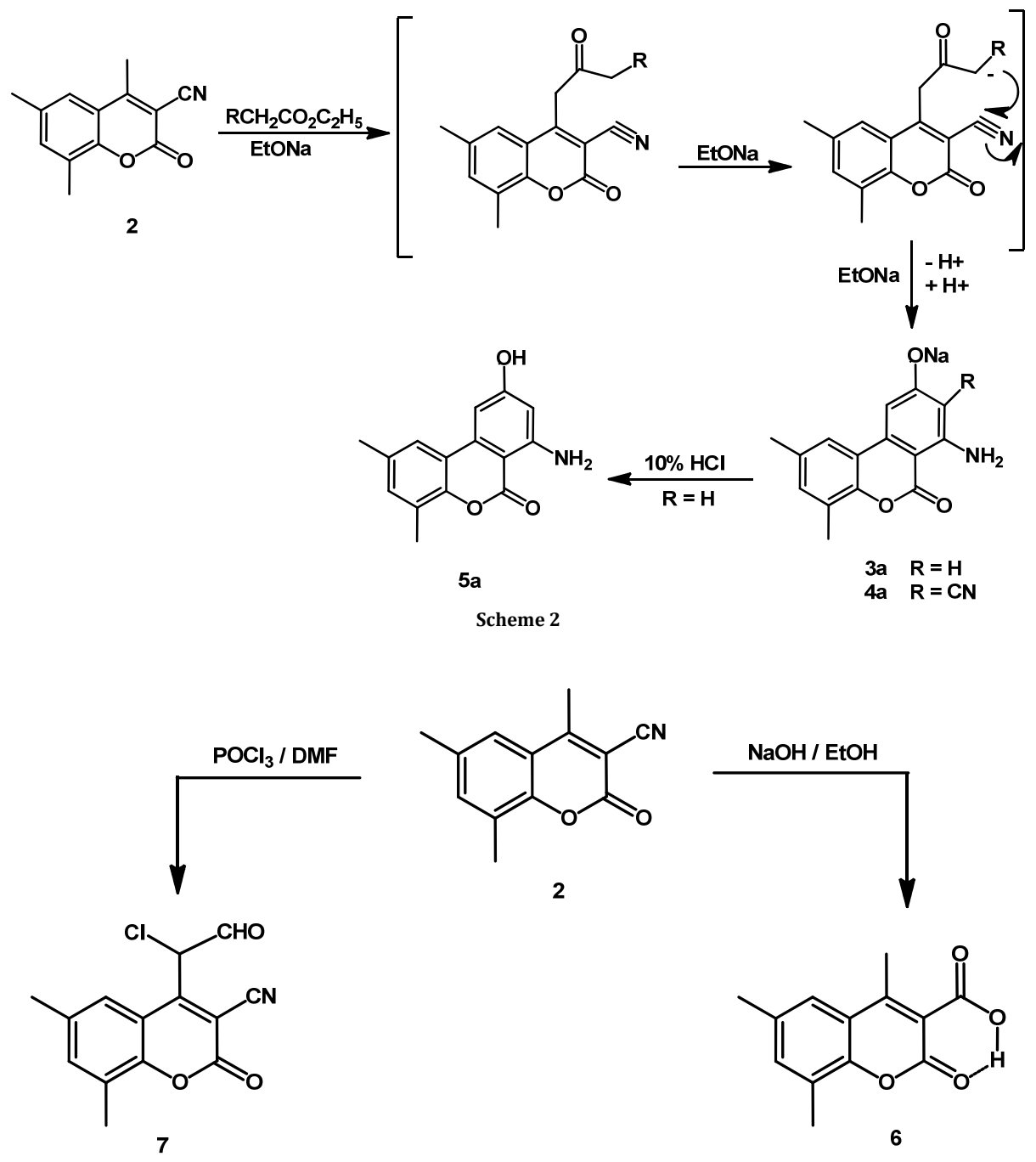

Scheme 3

${ }^{1} \mathrm{H}$ NMR (300 MHz, DMSO- $\left.d_{6}, \delta, \mathrm{ppm}\right): 2.19\left(\mathrm{~s}, 3 \mathrm{H}, \mathrm{CH}_{3}\right.$ ), $2.25\left(\mathrm{~s}, 3 \mathrm{H}, \mathrm{CH}_{3}\right), 2.31\left(\mathrm{~s}, 3 \mathrm{H}, \mathrm{CH}_{3}\right), 6.17(\mathrm{~s}, 1 \mathrm{H}, \mathrm{OH}$, exchangeable with $\left.\mathrm{D}_{2} \mathrm{O}\right), 7.18(\mathrm{~s}, 1 \mathrm{H}, H-7), 7.28(\mathrm{~s}, 1 \mathrm{H}, H-5) .{ }^{13} \mathrm{C}$ NMR (75 MHz, DMSO- $d_{6}, \delta$, ppm): $24.3,25.3,29.8,127.5,130.8$, 132.7, 134.3, 142.7, 144.1, 157.8, 158.3, 166.6, 175.3. MS (EI, $m / z(\%)): 231.0(\mathrm{M}-1,32.6), 232.0(\mathrm{M}+, 42.7), 233.0(\mathrm{M}+1$, 14.6). Anal. calcd. for $\mathrm{C}_{13} \mathrm{H}_{12} \mathrm{O}_{4}$ : C, 67.23; $\mathrm{H}, 5.21$. Found: $\mathrm{C}$, 67.20; H, 5.50\%.

\subsubsection{4-(Chloro(formyl)methyl-6,8-dimethyl-2-oxo-2H- chromene-3-carbonitrile (7)}

Phosphorusoxy chloride $\left(2.4 \mathrm{~cm}^{3}\right)$ was added dropwise to DMF $\left(6 \mathrm{~cm}^{3}\right)$ with stirring at $30-35{ }^{\circ} \mathrm{C}$, after the addition was completed, the solution was stirred at $50-60{ }^{\circ} \mathrm{C}$ for $30 \mathrm{~min}$. A solution of compound (2) $(1 \mathrm{~g}, 0.46 \mathrm{mmol})$ in dry pyridine $(6$ $\mathrm{cm}^{3}$ ) was added to the above mixture dropwise at $30-35^{\circ} \mathrm{C}$ and after the addition was completed, the mixture was stirred at $50-60{ }^{\circ} \mathrm{C}$ for $3 \mathrm{~h}$, cooled to room temperature. The mixture was poured over cold water. The solid obtained was filtered, and crystallized from DMF to give (7) as yellow crystals (Scheme 3). M.p.: $268-270{ }^{\circ} \mathrm{C}$. Yield: $85 \%$. FT-IR $\left(\mathrm{KBr}, \mathrm{cm}^{-1}\right)$ : 3422 (enolic $\mathrm{OH}), 2930,2958$ ( $\mathrm{CH}_{\text {aleph. }}$ ), 2722 ( $\left.\mathrm{CH}_{\text {aldehde }}\right), 2224(\mathrm{CN}), 1723$ (s, $\left.\mathrm{C}=\mathrm{O}_{\text {aldehyde }}\right), 1661(\mathrm{w}, \mathrm{C}=0$ coumarin), 1621 (exocyclic $\mathrm{C}=\mathrm{C}) .{ }^{1} \mathrm{H}$ NMR (300 MHz, DMSO- $\left.d_{6}, \delta, \mathrm{ppm}\right): 2.28\left(\mathrm{~s}, 3 \mathrm{H}, \mathrm{CH}_{3}\right), 2.32$ (s, 3H,
$\mathrm{CH}_{3}$ ), 7.14 (s, $\left.1 \mathrm{H}, \mathrm{CH}-\mathrm{Cl}\right), 7.44$ (s, $\left.1 \mathrm{H}, H-7\right), 7.69$ (s, $\left.1 \mathrm{H}, H-5\right), 9.01$ (s, $1 \mathrm{H}, \mathrm{CHO}) .{ }^{13} \mathrm{C}$ NMR (75 MHz, DMSO- $d_{6}, \delta, \mathrm{ppm}$ ): 24.4, 29.7, 55.8, 113.8, 124.0, 128.0, 135.1, 143.6, 146.7, 158.7, 166.4, 169.6, 170.5, 194.4. MS (EI, $m / z$ (\%)): 275.05 (M-1, 0.31), $276.05\left(\mathrm{M}^{+}, 0.20\right), 277.15(\mathrm{M}+1,0.59), 278.25(\mathrm{M}+2,2.49)$. Anal. calcd. for $\mathrm{C}_{14} \mathrm{H}_{10} \mathrm{ClNO}_{3}$ : C, 60.99; H, 3.66; N, 5.08. Found: C, $60.80 ; \mathrm{H}, 3.40 ; \mathrm{N}, 5.30 \%$. 2.2.6. 4-((E)-2-(Dimethylamino)vinyl)-6,8-dimethyl-2-oxo-
2H-chromene-3-carbonitrile (8)

Method A: A solution of compound (2) $(0.5 \mathrm{~g}, 0.23 \mathrm{mmol})$ in dry xylene $\left(10 \mathrm{~cm}^{3}\right)$, and then DMF-DMA $\left(0.35 \mathrm{~cm}^{3}, 0.29 \mathrm{mmol}\right)$ was added and the mixture was refluxed for $0.5 \mathrm{~h}$, cooled to room temperature. The solid obtained was filtered, and crystallized from DMF to give (8) as green crystals (Scheme 4). M.p.: $271-272{ }^{\circ} \mathrm{C}$. Yield: $63 \%$. FT-IR $\left(\mathrm{KBr}, \mathrm{cm}^{-1}\right): 3438$ (br., OH), 2935, 2999 ( $\left.\mathrm{CH}_{\text {aleph. }}\right), 2202(\mathrm{CN}), 1676(\mathrm{C}=0), 1618(\mathrm{C}=\mathrm{C}) .{ }^{1} \mathrm{H}$ NMR (300 MHz, DMSO- $\left.d_{6}, \delta, \mathrm{ppm}\right): 2.28\left(\mathrm{~s}, 6 \mathrm{H}, \mathrm{CH}_{3}\right), 2.35(\mathrm{~s}, 3 \mathrm{H}$, $\left.\mathrm{CH}_{3}\right), 2.49\left(\mathrm{~s}, 3 \mathrm{H}, \mathrm{CH}_{3}\right), 5.71(\mathrm{~d}, J=12.6 \mathrm{~Hz}, 1 \mathrm{H}, H-9), 7.31(\mathrm{~s}, 1 \mathrm{H}$, $H-7), 7.73$ (s, 1H, $H-5$ ), 8.45 (d, $J=12.3 \mathrm{~Hz}, 1 \mathrm{H}, H-10$ ). ${ }^{13} \mathrm{C}$ NMR (75 MHz, DMSO- $\left.d_{6}, \delta, \mathrm{ppm}\right): 18.4,24.8,29.8,46.7,55.3,97.6$, $108.8,126.4,129.3,132.3,135.0,142.4,144.8,164.3,238.5$. 

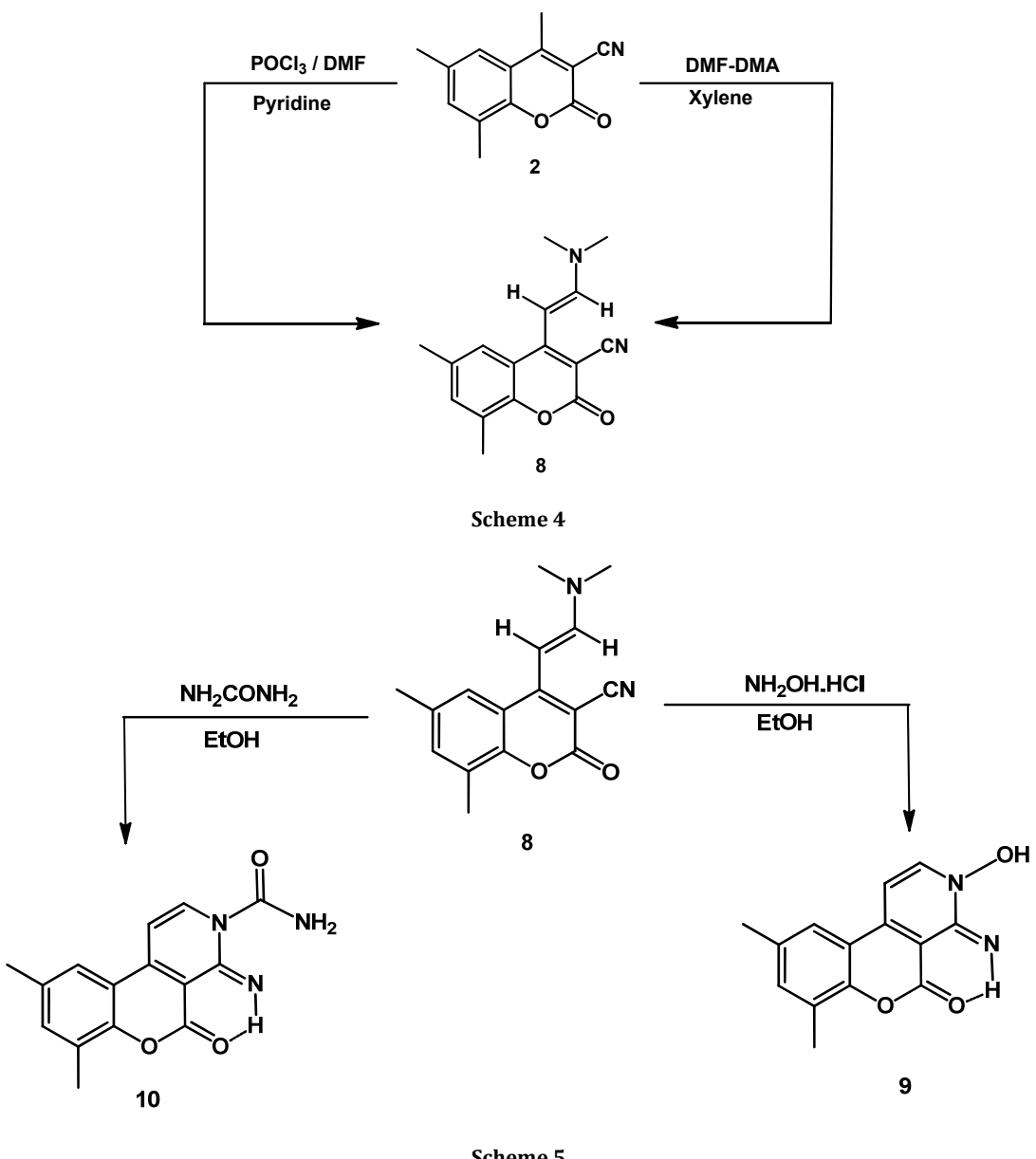

Scheme 5

MS (EI, $m / z$ (\%)): 266.0 (M-2, 8.3), 267.0 (M-1, 26.1), 268.0 $\left(\mathrm{M}^{+}, 100\right)$. Anal. calcd. for $\mathrm{C}_{16} \mathrm{H}_{16} \mathrm{~N}_{2} \mathrm{O}_{2}$ : C, 71.62; $\mathrm{H}, 6.01 ; \mathrm{N}$, 10.44. Found: C, $71.20 ; \mathrm{H}, 6.20 ; \mathrm{N}, 10.50 \%$.

Method B: A mixture of DMF $\left(5 \mathrm{~cm}^{3}\right)$, phosphorusoxy chloride $\left(0.5 \mathrm{~cm}^{3}\right)$ and a solution of compound (2) $(0.5 \mathrm{~g}, 0.23$ mmol) in dry pyridine $\left(6 \mathrm{~cm}^{3}\right)$ was stirred at $70-80{ }^{\circ} \mathrm{C}$ for $3 \mathrm{~h}$, cooled to room temperature. The mixture was poured over cold water and neutralized with sodium carbonate solution. The solid obtained was filtered, and crystallized from DMF to give (8) as green crystals, M.p.: $272{ }^{\circ} \mathrm{C}$. Yield: $60 \%$.

\subsubsection{3,4-Dihydro-3-hydroxy-4-imino-7,9-dimethylchromeno [3,4-c]pyridin-5-one (9)}

A mixture of compound (8) (0.5 g, 0.19 mmol), hydroxylamine hydrochloride $(0.13 \mathrm{~g}, 0.19 \mathrm{mmol})$, absolute ethanol $\left(15 \mathrm{~cm}^{3}\right)$, and drops of acetic acid was refluxed for $3 \mathrm{~h}$, cooled to room temperature. The solid obtained was filtered, and crystallized from DMF to give (9) as yellow crystals (Scheme 5). M.p.: $315-316{ }^{\circ} \mathrm{C}$. Yield: $85 \%$. FT-IR $\left(\mathrm{KBr}, \mathrm{cm}^{-1}\right)$ : 3414 (br., OH), 3223 (br., NH), 2920 ( $\mathrm{CH}_{\text {aleph.) }} 1702$ (C=0), 1625 (exocyclic $\mathrm{C}=\mathrm{N}$ ). ${ }^{1} \mathrm{H}$ NMR $\left(300 \mathrm{MHz}, \mathrm{DMSO}-d_{6}, \delta, \mathrm{ppm}\right)$ : $2.34\left(\mathrm{~s}, 3 \mathrm{H}, \mathrm{CH}_{3}\right), 2.50\left(\mathrm{~s}, 3 \mathrm{H}, \mathrm{CH}_{3}\right), 7.31(\mathrm{~s}, 1 \mathrm{H}, H-8), 7.52$ (d, $J=$ $7.4 \mathrm{~Hz}, 1 \mathrm{H}, H-1), 7.92$ (s, 1H, H-10), 8.00 (s, 1H, NH, exchangeable with $\left.\mathrm{D}_{2} \mathrm{O}\right), 8.30(\mathrm{~s}, 1 \mathrm{H}, \mathrm{OH}$, exchangeable with $\left.\mathrm{D}_{2} \mathrm{O}\right), 8.50((\mathrm{~d}, J=7.2 \mathrm{~Hz}, 1 \mathrm{H}, H-2)$. MS (EI, $m / z(\%)): 256.0(\mathrm{M}+$, 4.5), $256.8(\mathrm{M}+1,2.7)$. Anal. calcd. for $\mathrm{C}_{14} \mathrm{H}_{12} \mathrm{~N}_{2} \mathrm{O}_{3}$ : C, 65.62; $\mathrm{H}$, 4.72; N, 10.93. Found: C, 65.30; H, 4.60; N, 11.1\%.

\subsubsection{4-Imino-7,9-dimethyl-5-oxo-4H-chromeno[3,4-c] pyridine-3(5H)-carboxamide (10)}

A mixture of compound (8) $(0.5 \mathrm{~g}, 0.19 \mathrm{mmol})$, urea $(0.11 \mathrm{~g}$ $0.19 \mathrm{mmol})$, and glacial acetic acid $\left(10 \mathrm{~cm}^{3}\right)$ was refluxed for 3 $\mathrm{h}$, cooled to room temperature. The solid obtained was filtered, and crystallized from DMF to give (10) as green crystals (Scheme 5). M.p.: $>300{ }^{\circ} \mathrm{C}$. Yield: 47\%. FT-IR ( $\left.\mathrm{KBr}, \mathrm{cm}^{-1}\right)$ : 3452,

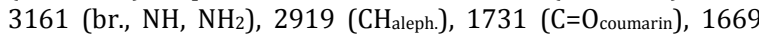
(C=0 amide). MS (EI, $m / z(\%)): 280.0$ (M-3, 18.8), 281.0 (M-2, 2.6). Anal. calcd. for $\mathrm{C}_{15} \mathrm{H}_{13} \mathrm{~N}_{3} \mathrm{O}_{3}: \mathrm{C}, 63.60 ; \mathrm{H}, 4.63 ; \mathrm{N}, 14.83$. Found: C, 63.40; H, 4.20; N, 14.60\%.

\subsubsection{3-Amino-3,4-dihydro-4-imino-7,9-dimethylchromeno [3,4-c]pyridin-5-one (11)}

A mixture of compound (8) $(0.5 \mathrm{~g}, 0.19 \mathrm{mmol})$, hydrazinecarbodithioic acid (0.2 g, $0.19 \mathrm{mmol})$, and glacial acetic acid $\left(10 \mathrm{~cm}^{3}\right)$ was refluxed for $3 \mathrm{~h}$, cooled to room temperature. The solid obtained was filtered, and crystallized from DMF to give (10) as yellow crystals (Scheme 6). M.p.: $>300{ }^{\circ} \mathrm{C}$. Yield: 73\%. FT-IR (KBr, cm ${ }^{-1}$ ): 3359, 3096 (br., $\mathrm{NH}$, $\mathrm{NH}_{2}$ ), 2970, 2919 ( $\mathrm{CH}_{\text {aleph.) }}, 1728$ (C=O coumarin), 1626 (exocyclic $\mathrm{C}=\mathrm{N}), 1605(\mathrm{C}=\mathrm{C}) .{ }^{1} \mathrm{H}$ NMR $\left(300 \mathrm{MHz}, \mathrm{DMSO}-d_{6}, \delta, \mathrm{ppm}\right): 2.36$ (s, 3H, $\left.\mathrm{CH}_{3}\right), 2.46\left(\mathrm{~s}, 3 \mathrm{H}, \mathrm{CH}_{3}\right), 4.03\left(\mathrm{~s}, 2 \mathrm{H}, \mathrm{NH}_{2}\right.$, exchangeable with $\mathrm{D}_{2} \mathrm{O}$ ), 7.35 (br. S, $\left.1 \mathrm{H}, H-1\right), 8.00(\mathrm{~s}, 1 \mathrm{H}, H-8), 8.06(\mathrm{~s}, 1 \mathrm{H}, H$ 10), 9.20 (br. S, $1 \mathrm{H}, H-2$ ). MS (EI, $m / z(\%)$ ): 254.0 (M-1, 1.0), $255.0\left(\mathrm{M}^{+}, 27.9\right), 256.0(\mathrm{M}+1,37.9), 257.0(\mathrm{M}+2,6.4)$. Anal. calcd. for $\mathrm{C}_{14} \mathrm{H}_{13} \mathrm{~N}_{3} \mathrm{O}_{2}$ : C, 65.87; $\mathrm{H}, 5.13 ; \mathrm{N}, 16.46$. Found: $\mathrm{C}$, 65.60; H, 5.00; N, 16.10\%. 


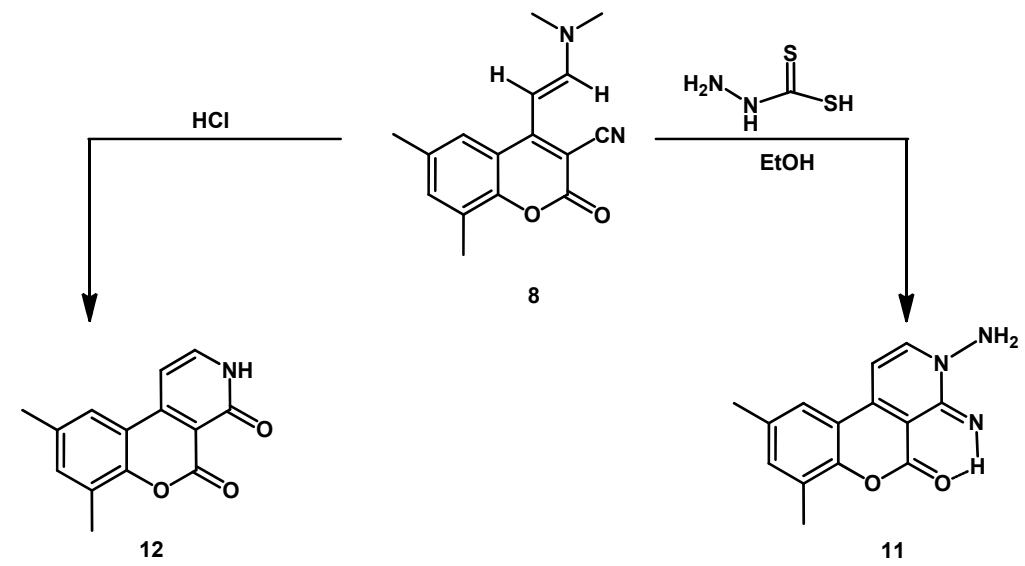

Scheme 6

\subsubsection{7,9-Dimethyl-3H-chromeno[3,4-c]pyridine-4,5-dione (12)}

A mixture of compound (8) $(0.4 \mathrm{~g}, 0.15 \mathrm{mmol})$, and conc. hydrochloric acid $\left(3 \mathrm{~cm}^{3}\right)$, was stirred at $60-70{ }^{\circ} \mathrm{C}$ for $0.5 \mathrm{~h}$, cooled to room temperature and diluted with water $\left(5 \mathrm{~cm}^{3}\right)$. The solid obtained was filtered, and crystallized from DMF to give (12) as yellow crystals (Scheme 6). M.p.: 303-304 ${ }^{\circ} \mathrm{C}$. Yield: 82\%. FT-IR ( $\mathrm{KBr}, \mathrm{cm}^{-1}$ ): 3166 (br., NH), 1732 (s, C=O coumarin $_{\text {), }}$ 1667 ( $\left.\mathrm{w}, \mathrm{C}=\mathrm{O}_{\text {amide }}\right), 1620$ (C=C). ${ }^{1} \mathrm{H}$ NMR $\left(300 \mathrm{MHz}, \mathrm{DMSO}-d_{6}, \delta\right.$, ppm): 2.29 (s, 3H, $\left.\mathrm{CH}_{3}\right), 2.33\left(\mathrm{~s}, 3 \mathrm{H}, \mathrm{CH}_{3}\right), 7.10-7.20(\mathrm{~m}, 2 \mathrm{H}, \mathrm{H}-1$, $H-8), 7.80(\mathrm{~s}, 1 \mathrm{H}, H-10), 9.40(\mathrm{~S}, 1 \mathrm{H}, H-2)$. MS (EI, $m / z(\%)$ ): $241.0\left(\mathrm{M}^{+}, 100\right), 242.0(\mathrm{M}+1,21.7)$. Anal. calcd. for $\mathrm{C}_{14} \mathrm{H}_{11} \mathrm{NO}_{3}$ : C, 69.70; H, 4.60; N, 5.81. Found: C, 69.50; H, 4.50; N, 5.60\%.

\section{Results and discussion}

\subsection{Chemistry}

The Claisen condensation of 2-hydroxyacetophenone derivatives with ethyl acetate in the presence of sodium metal gave $\beta$-dicarbonyl compound derivatives which were cyclized under the effect of concentrated sulfuric acid to give 2methylchromone derivatives [17]

In our recent work [2], we described the Claisen condensation of 3,5-dichloro-2-hydroxyacetophenone and unsubstituted 2-hydroxyacetophenone with ethyl cyanoacetate in the presence of sodium metal gave 7-amino-2,4-dichloro-9hydroxy-6-oxo-6H-benzo[c]chromene-8-carbonitrile and a mixture of 4-methyl-2-oxo-2H-chromene-3-carbonitrile and 7amino-9-hydroxy-6-oxo-6H-benzo[c]chromene-8-carbonitrile, respectively.

The present work describes the Claisen condensation of 3,5-dimethyl-2-hydroxyacetophenone with ethyl cyanoacetate in the presence of sodium metal to give 4,6,8-trimethyl-2-oxo$2 \mathrm{H}$-chromene-3-carbonitrile (2) (Scheme 1). The presence of cyano group in a position 3 activates the methyl group in a position 4 of compound (2) which facilitates the cyclocondensation reactions with ester derivatives containing active methylene group, so the reaction of compound (2) with ethyl acetate or with ethyl cyanoacetate in the presence of ethoxide gave sodium salt of 7-amino-9-hydroxy-2,4-dimethyl-6Hbenzo[c]chromen-6-one derivatives (3) and (4) respectively (Scheme 1). When the sodium salt of compound (3) was neutralized with $10 \%$ hydrochloric acid gave 7-amino-9hydroxy-2,4-dimethyl-6H-benzo[c]chromen-6-one (5) (Scheme 1).
The formation of compounds $\mathbf{3 a}, \mathbf{4 a}$ and $\mathbf{5 a}$ proceeded via Claisen condensation on active methyl group of compound (2) followed by nucleophilic cyclization (Scheme 2).

The hydrolysis of cyano group of 4,6,8-trimethyl-2-oxo- $2 \mathrm{H}$ chromene-3-carbonitrile (2) in ethanolic sodium hydroxide solution gave 4,6,8-trimethyl-2-oxo- $2 \mathrm{H}$-chromene-3-carboxylic acid (6) (Scheme 3). Also, the Vilsmier reaction of compound (2) in excess $\mathrm{POCl}_{3}$ gave 4-(chloro(formyl)methyl-6,8dimethyl-2-oxo-2H-chromene-3-carbonitrile (7) (Scheme 3).

The presence of carbonyl group in a position 2 and cyano group in a position 3 of coumarin moiety facilitate the condensation reactions of 4-methyl group of coumarin, so the reaction of DMF-DMA with compound (2) in dry xylene gave 4-((E)-2-(dimethylamino)vinyl)-6,8-dimethyl-2-oxo- $2 \mathrm{H}$ chromene-3-carbonitrile (8). Also, compound (8) was formed by condensation with dimethylformamide in the presence of $\mathrm{POCl}_{3}$ (Scheme 4). The compound (8) was formed in the form of $E$-isomer from ${ }^{1} \mathrm{H}$ NMR spectra which showed $J_{\mathrm{CH}=\mathrm{CH}}=12.3 \mathrm{~Hz}$ at $\delta=5.71$ and $8.45 \mathrm{ppm}$.

The cyclocondensation reactions of 4-((E)-2-(dimethyl amino)vinyl)-6,8-dimethyl-2-oxo- $2 H$-chromene-3-carbonitrile (8) with primary amines in ethanol gave 4-imino-7,9dimethylchromeno[3,4-c]pyridine derivatives. The cyclo condensation reactions of compound (8) with hydroxylamine hydrochloride, urea, and with hydrazinecarbodithioic acid gave 3,4-dihydro-3-hydroxy-4-imino-7,9-dimethylchromeno[3,4-c] pyridin-5-one (9), 4-imino-7,9-dimethyl-5-oxo-4H-chromeno [3,4-c]pyridine-3 $(5 H)$-carboxamide (10) (Scheme 5) and 3-amino-3,4-dihydro-4-imino-7,9-dimethylchromeno[3,4-c] pyridin-5-one (11) (Scheme 6) respectively. Also, the cyclocondensation reaction of compound (8) by acid hydrolysis of cyano group, followed by cyclization to give 7,9-dimethyl$3 H$-chromeno[3,4-c]pyridine-4,5-dione (12) (Scheme 6).

The formation of cyclocondensation products (9-11) proceeded via the nucleophilic replacement of $\mathrm{NH}_{2}$ group of amine derivatives to $-\mathrm{N}\left(\mathrm{CH}_{3}\right)_{2}$ group of compound $\mathbf{8}$ to give the intermediate products 13 , which can be cyclised by nucleophilic addition of $\mathrm{NH}$ group to $\mathrm{C} \equiv \mathrm{N}$ group (Scheme 7).

\subsection{Molecular orbital calculations}

The experimental IR frequencies of $\mathrm{C}=\mathrm{O}$ groups of coumarin derivatives were compared with theoretical bond lengths of $\mathrm{C}=0$ groups which were obtained from molecular mechanical calculations on the basis of the semi-empirical AM1 and $\mathrm{Ab}$ Initio (STO-3G) methods of HyperChem 8.03 computer program after geometrical optimization of the structures for compounds (2-12) (Table 1). 


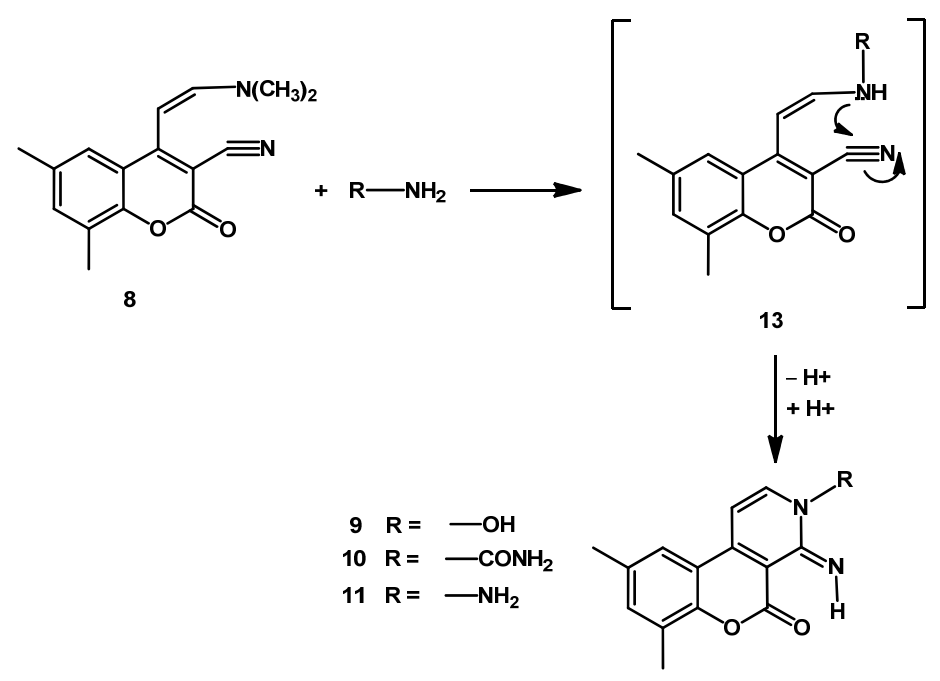

Scheme 7

Table 1. Calculated bond lengths of $\mathrm{C}=0$ of coumarin derivatives by Semi-empirical AM1 and $A b$ initio (STO-3G) methods and their experimental IR vC=0 values for compounds (2-12).

\begin{tabular}{|c|c|c|c|}
\hline Compound & $\begin{array}{l}\text { Bond lengths of } \mathrm{C}=0(\AA) \\
\text { (by Semi-empirical AM1) }\end{array}$ & $\begin{array}{l}\text { Bond lengths of } \mathrm{C}=0(\AA) \\
{[\text { by } A b \text { Initio (STO-3G)] }}\end{array}$ & Experimental $v \mathrm{C}=0$ values, $\mathrm{cm}^{-1}$ \\
\hline 2 & 1.22839 & 1.22747 & 1721 \\
\hline $3 a$ & $1.22773^{\mathrm{a}}$ & $1.22604^{\mathrm{a}}$ & 1721 \\
\hline $3 b$ & $1.24427^{b}$ & $1.23136^{\mathrm{b}}$ & 1655 \\
\hline $4 a$ & $1.23752^{\mathrm{a}}$ & $1.22672^{\mathrm{a}}$ & 1623 \\
\hline $4 b$ & $1.24197 \mathrm{~b}$ & $1.22866^{b}$ & 1623 \\
\hline $5 b$ & $1.22443^{\mathrm{a}}$ & $1.22461^{\mathrm{a}}$ & 1725 \\
\hline $5 b$ & $1.2416^{\mathrm{b}}$ & $1.22477^{b}$ & 1666 \\
\hline 6 & $1.24879^{a}$ & $1.21852^{\mathrm{a}}$ & 1660 \\
\hline 6 & $1.22183^{\mathrm{c}}$ & $1.21744^{\mathrm{c}}$ & 1742 \\
\hline 7 & $1.24793^{\mathrm{a}}$ & $1.21722^{\mathrm{a}}$ & 1661 \\
\hline 7 & $1.22641^{\mathrm{d}}$ & $1.22441^{\mathrm{d}}$ & 1723 \\
\hline 8 & 1.23984 & 1.2181 & 1676 \\
\hline 9 & 1.22692 & 1.22684 & 1702 \\
\hline 10 & $1.22807 \mathrm{a}$ & $1.22699 \mathrm{a}$ & 1731 \\
\hline 10 & $1.24126^{\mathrm{e}}$ & $1.21657 \mathrm{e}$ & 1669 \\
\hline 11 & 1.22723 & 1.22662 & 1728 \\
\hline 12 & $1.22718^{\mathrm{a}}$ & $1.21812^{\mathrm{a}}$ & 1732 \\
\hline 12 & $1.24092 \mathrm{e}$ & $1.22168 \mathrm{e}$ & 1667 \\
\hline $\begin{array}{l}\text { a } \mathrm{C}=\mathrm{O}_{\text {coumarin }} \\
\text { b } \mathrm{C}=\mathrm{O}_{\text {cyclic keton }} \\
\text { c } \mathrm{C}=\mathrm{O}_{\text {acid }} \\
\mathrm{d} \mathrm{C}=\mathrm{O}_{\text {aldehyde }} \\
\text { e } \mathrm{C}=\mathrm{O}_{\text {amide }}\end{array}$ & & & \\
\hline
\end{tabular}

The calculated bond lengths of $\mathrm{C}=0$ groups $(\AA)$ on the basis of semi-empirical AM1 method are linearly related to the measured IR $v_{\mathrm{C}=0}$ groups $\left(\mathrm{cm}^{-1}\right)$ for compounds (2-12) and from the linear relation bond length $(\mathrm{C}=0)=1.699-2.743 v_{\mathrm{C}=0}, r=$ 0.913 except $4 \mathbf{a}, \mathbf{4 b}$ (br. band of $v_{\mathrm{C}=0}$ ), where $r$ is regression coefficient. The negative slope reveals indirect proportionality of the calculated bond lengths with measured $v_{\mathrm{C}=0}$ values, which agreement with Hooke's law and these support the proposed structures for the prepared compounds. On the other hand, when $A b$ initio (STO-3G) method was used, the linear relation between bond length $(\mathrm{C}=0)$ and $v_{\mathrm{C}=0}$ not agreement which is less efficient method than the semi-empirical AM1 method.

\subsection{Antimicrobial activity}

The newly synthesized compounds were screened against Gram-positive bacteria: Staphylococcus aureus (ATCC 25923) and Bacillus subtilis (ATCC 6635), Gram-negative bacteria: Salmonella typhimurium (ATCC 14028) and Escherichia coli (ATCC 25922), Yeast: Candida albicans (ATCC 10231) and Fungus: Aspergillus fumigatus. The standardized disc-agar diffusion method [18] was followed to determine the activity of the synthesized compounds against the tested microorganisms.

The tested compounds were dissolved in dimethyl formamide (DMF) solvent and prepared in two concentrations 2 and $1 \mathrm{mg} / \mathrm{mL}$. The antibiotic chloramphencol was used as standard reference in the case of Gram-negative bacteria, Cephalothin was used as standard reference in the case of Gram-positive bacteria and cycloheximide was used as standard reference in the case of yeasts and fungi. Compound 9 showed high activities against Aspergillus fumigates at concentration of $2 \mathrm{mg}$ and $1 \mathrm{mg}$, while it showed intermediate activities against Bacillus subtilis, Escherichia coli and Candida albicans (Table 2).

\section{Acknowledgements}

I am particularly gratitude to Dr. Ibrahim Hassan, Department of Plant Protection, Faculty of Agriculture, AlAzhar University, for his kind cooperation in carrying out the antimicrobial screening throughout this work. 
Table 2. Antimicrobial activities data of compounds (2-12).

\begin{tabular}{|c|c|c|c|c|c|c|c|c|c|c|c|c|}
\hline \multirow{5}{*}{ Sample } & \multicolumn{4}{|c|}{ Gram-positive bacteria } & \multicolumn{4}{|c|}{ Gram-negative bacteria } & \multicolumn{4}{|c|}{ Yeastsb } \\
\hline & \multirow{2}{*}{\multicolumn{2}{|c|}{$\begin{array}{c}\begin{array}{c}\text { Staphylococcus aureus } \\
\text { (ATCC 25923) }\end{array} \\
\text { Concentrationg }\end{array}$}} & \multirow{2}{*}{\multicolumn{2}{|c|}{$\begin{array}{c}\text { Bacillus subtilis } \\
\text { (ATCC 6635) }\end{array}$}} & \multirow{2}{*}{\multicolumn{2}{|c|}{$\begin{array}{c}\begin{array}{c}\text { Salmonella typhimurium } \\
\text { (ATCC 14028) }\end{array} \\
\text { Concentrationg }\end{array}$}} & \multirow{2}{*}{\multicolumn{2}{|c|}{$\begin{array}{l}\text { Escherichia coli } \\
\text { (ATCC 25922) } \\
\text { Concentrationg }\end{array}$}} & \multirow{2}{*}{\multicolumn{2}{|c|}{$\begin{array}{c}\begin{array}{c}\text { Candida albicans } \\
\text { (ATCC 10231) }\end{array} \\
\text { Concentrationg }\end{array}$}} & \multicolumn{2}{|c|}{ Aspergillus fumigatus } \\
\hline & & & & & & & & & & & Conc & tiong \\
\hline & 2 & 1 & 2 & 1 & 2 & 1 & 2 & 1 & 2 & 1 & 2 & 1 \\
\hline & \multicolumn{12}{|c|}{ Mean of zone diametera, mm } \\
\hline 2 & -c & - & - & - & - & - & - & - & - & - & - & - \\
\hline 3 & $3 L^{d}$ & - & $2 \mathrm{~L}$ & - & $2 \mathrm{~L}$ & - & $2 \mathrm{~L}$ & - & $3 \mathrm{~L}$ & - & - & - \\
\hline 4 & $4 \mathrm{~L}$ & - & $2 \mathrm{~L}$ & - & $5 \mathrm{~L}$ & $3 \mathrm{~L}$ & $2 \mathrm{~L}$ & - & - & - & $2 \mathrm{~L}$ & - \\
\hline 5 & - & - & $3 \mathrm{~L}$ & - & - & - & - & - & $2 \mathrm{~L}$ & - & $5 \mathrm{~L}$ & $2 \mathrm{~L}$ \\
\hline 6 & $4 \mathrm{~L}$ & - & $6 \mathrm{~L}$ & $3 \mathrm{~L}$ & $4 \mathrm{~L}$ & $2 \mathrm{~L}$ & $5 \mathrm{~L}$ & $2 \mathrm{~L}$ & $3 \mathrm{~L}$ & - & - & - \\
\hline 7 & $2 \mathrm{~L}$ & - & $4 \mathrm{~L}$ & $2 \mathrm{~L}$ & $3 \mathrm{~L}$ & - & - & - & $4 \mathrm{~L}$ & - & - & - \\
\hline 8 & $2 \mathrm{~L}$ & - & $3 \mathrm{~L}$ & - & - & - & - & - & - & - & - & - \\
\hline 9 & $8 \mathrm{~L}$ & $4 \mathrm{~L}$ & $15 \mathrm{I}$ & $11 \mathrm{~L}$ & $6 \mathrm{~L}$ & - & $18 \mathrm{I}$ & $14 \mathrm{I}$ & $20 \mathrm{I}$ & $17 \mathrm{I}$ & $29 \mathrm{H}^{\mathrm{f}}$ & $21 \mathrm{H}$ \\
\hline 10 & - & - & $3 \mathrm{~L}$ & - & - & - & $3 \mathrm{~L}$ & - & $2 \mathrm{~L}$ & - & $2 \mathrm{~L}$ & - \\
\hline 11 & $2 \mathrm{~L}$ & - & - & - & - & - & - & - & $4 \mathrm{~L}$ & - & - & - \\
\hline 12 & - & - & $2 \mathrm{~L}$ & - & - & - & - & - & - & - & - & - \\
\hline Control $^{\mathrm{h}}$ & 42 & 28 & 38 & 30 & 36 & 25 & 38 & 30 & 40 & 28 & 40 & 31 \\
\hline
\end{tabular}

$\mathrm{b}$ Identified on the basis of routine cultural, morphological and microscopical characteristics.

c - : No effect.

${ }^{d}$ L: Low activity $=$ Mean of zone diameter $\leq 1 / 3$ of mean zone diameter of control.

e I: Intermediate activity = Mean of zone diameter $\leq 2 / 3$ of mean zone diameter of control.

${ }^{\mathrm{f}} \mathrm{H}$ : High activity $=$ Mean of zone diameter $>2 / 3$ of mean zone diameter of control.

$\mathrm{g}$ Concentration, $\mathrm{mg} / \mathrm{mL}$.

h Chloramphencol in the case of Gram-positive bacteria, Cephalothin in the case of Gram-negative bacteria and cycloheximide in the case of fungi.

\section{References}

[1]. El-Shaaer, H. M.; Abdel-Aziz, S. A.; Hanafy, F. I.; Ali, T. E.; El-Fauomy, A. Z. Eur. J. Chem. 2011, 2(2), 158-162.

[2]. El-Shaaer, H. M. Eur. J. Chem. 2012, 3(1), 51-56

[3]. Ali, T. E.; Abdel-Aziz, S. A.; El-Shaaer, H. M.; Hanafy, F. I.; El-Fauomy, A. Z. Phosphorus, Sulfur, and Silicon 2008, 183, 2139-2160.

[4]. Ali, T. E.; Abdel-Aziz, S. A.; El-Shaaer, H. M.; Hanafy, F. I.; El-Fauomy, A. Z. Turk. J. Chem. 2008, 32, 365-374.

[5]. El-Sayed, A. M.; Abdallah, O. A. Phosphorus, Sulfur, and Silicon 2001, $170,75-86$

[6]. El-Shaaer, H. M.; Foltinova, P.; Lacova, M.; Chovancova, J.; Stankovicova, H. Il Farmaco 1998, 53, 224-232.

[7]. Gasparova, R.; Lacova, M.; El-Shaaer, H. M.; Odlerova, Z. Il Farmaco 1997, 52, 251-253.

[8]. Manolov, I.; Maichle-Moessmer, C.; Danchev, N. Eur. J. Med. Chem. 2006, 41, 882-890.

[9]. Manolov, I.; Maichle-Moessmer, C.; Nicolova, I.; Danchev, N. Arch. Pharm. 2006, 336, 319-326.

[10]. Jackson, S. A.; Sahni, S.; Lee, L.; Luo, Y.; Nieduzak, T. R. Bioorg. Med. Chem. 2005, 13, 2723-2739.

[11]. Choudhary, M.; Fatima, N.; Khan, K.; Jalil, S.; Iqbal, S.; Rahman, A. Bioorg. Med. Chem. 2006, 14, 8066-8072.

[12]. Cravotto, G.; Tagliapietra, S.; Cappelo, R.; Palmisano, G.; Curini, M.; Boccalini, M. Arch. Pharm. 2006, 336, 129-132.

[13]. Ishar, M. P. S.; Singh, G.; Singh, S.; Sreenivasan, K. K.; Singh, G. Bioorg. Med. Chem. Lett. 2006, 16, 1366-1370.

[14]. Liu, J.; Wu, J.; Zhao, Y. X.; Deng, Y. Y.; Mei, W. L.; Dai, H. F. Chin. Chem. Lett. 2008, 19, 934-936

[15]. Lacova, M.; Gasparova, R.; Kois, P.; Bohac, A.; El-Shaaer, H. M. Tetrahedron 2010, 66, 1410-1419.

[16]. Gaplovsky, A.; Donovalova, J.; Lacova, M.; Mracnova, R.; El-Shaaer, H. M. J. Photochem. Photobiol. A 2000, 136, 61-65.

[17]. El-Shaaer, H. M.; Perjessy, A.; Zahradnik, P.; Lacova, M.; Sustekova, Z. Monatsh. Chem. 1993, 124, 539-548.

[18]. Bauer, A. W.; Kirby, W. W. M.; Sherris, J. C.; Turck, M. Am. J. Clin. Pathol. 1966, 45, 493-496. 